\title{
Organ donation and transplantation within the Zulu culture
}

\author{
BR Bhengu, PhD, School of Nursing, University of KwaZulu-Natal \\ (Work done while a student at RAU) \\ HHM Uys, D Cur (Intensive General Nursing), *Department of Nursing, RAU \\ ( ${ }^{\star}$ At the time of research)
}

\section{Abstract}

Greater knowledge and technological advancement in the field of transplantation has increased the demand for organ donation beyond the supply of organs, especially among the black communities. This imbalance arises from the few sources of organs, limitations on the techniques of organ retrieval, disparities in the allocation of organs and socio-cultural factors.

The aim of this study was to investigate the extent to which Zulu cultural norms and social structures influence an individual's decision to donate an organ or to undergo transplantation.

A qualitative approach using an ethno-nursing method was selected. Semi-structured interviews were conducted with a transplant co-ordinator representing the professional sector, with traditional healers and religious leaders representing the folk sector, and with the general public representing the popular sector of the health care system. Both urban and rural settings were used. Conclusions arrived at showed that knowledge was lacking among Zulu speaking people about organ donation and transplantation and misconceptions about the topic were related to Zulu life patterns, beliefs about death, burial and life hereafter, and values and social structures. Recommendations with regard to the promotion of organ donation and transplantation among Zulu speaking people were made based on culture-sensitive and culture-congruent principles.

\section{Opsomming}

Toename in kennis en tegnologiese vordering op die terrein van orgaanoorplanting het aanleiding tot ? toename in aanvraag na organe tot gevolg gehad. Die aanbod van organe bevredig egter nie die aanvraag nie in die, swart gemeenskap nie. Navorsing skryf hierdie wanbalans toe aan ? beperkte bron van organe, tegnieke van orgaanherwinning, wanpraktyke met betiekking tot die toekenning van organe en sosiokulturele faktore toe.Die doel met hierdie studie was om die mate waartoe die Zoeloesprekende bevolking se kulturele norme en sosiaal - gestruktureerde dimensies, die individu se besluit om ' $n$ orgaan te skenk en oorplanting te ondergaan bëinvloed. 'n Kwalititiewe benadering geskoei op die etno-verpleegingsmetode was gebruik. Semi-gestrukturende onderhoude is met onder andere die volgende gevoer: 'n Oorplantingskoördineerder (professionele sektor), godsdienstige leiers, tradisionele geneesers ("folk" sector) en die algemene publiek. Respondente is uit sowel landelike as stedelike gebiede betrek. Die gevolgtrekkings wat uit hierdie studie voortspruit, dui daarop dat daar oor die algemeen ' $n$ gebrek aan kennis is rakende organskenking en orgaanoorplanting. Dit is hoofsaaklik te danke aan wanopwattings/geloofsoortuigings rakende die dood, lewe na die dood, eiesoortige waardesteltsels en sosiaalgestruktureerde dimensies. Die aanbevelings met betrekking tot die aanmoediging van orgaanskenking en orplantings onder Zoeloesprekende persone is op kultuursensitiewe en kultuur ongruente beginsels geskoei.

\section{Introduction and problem statement}

Greater knowledge and technical advances in the field of transplantation have increased the demand for organ donation beyond the current capacity to supply them. For example, the transplant waiting list in the United States in 1999 was 65793 patients growing at an average rate of $16 \%$ per year as against the cadaveric increase of $5.6 \%$ in 1998 (Razek, Olthoff \& Reilly, 2000: 1021; Ketchum, 2003: 1). In
South Africa, the transplant waiting list for all organ types in the year 2000 and 2001 respectively was 783 and 794 in the public sector while it was 180 and 258 in the private sector (http://www.geocities.com, 2003:7). This shortfall cannot be attributed only to ineffective organ harvesting techniques or to public ignorance, as cultural norms and social structures also play a major role.

\section{Cultural Diversities}

Organ donor referrals among Africans in 1995 and the year 2000 respectively were $28 \%$ and $17 \%$ while it was $60 \%$ and 
$72 \%$ among whites in South Africa. The actual number of donors in the same years were $7 \%$ and $12 \%$ among blacks while it was $77 \%$ and $76 \%$ among whites (http:// www.geocities.com, 20(03:3). African Americans are reportedly accounting for $13 \%$ of organ donors but $18 \%$ of organ recipients (transplant patients). African Americans have a high incidence of heart problems, diabetes mellitus and kidney disorders, all of which culminate in the need for transplantation. Studies have also shown that better matches are seen when an organ donor is from the same race because of genetic specificity (Yang, Abrams, Smolinski \& Nathan, 1993: 2487; Ketchum, 2003:1).

This racial or cultural discrepancy in organ donation was found to be caused by lack of knowledge, religious fears, fear of surgical complications and lack of communication between lay families and health care personnel among black Americans (Callender, cited in Pike, Kahn \& Jacobson, 1991:267). Pike et al (1991:267) therefore think such factors could also be true of South African blacks.

\section{Leininger's theory of transcultural nursing}

Faced with such cultural diversities, Leininger (1978:12) suggests development of a scientific and humanistic body of knowledge that provides for both culture-specific and universal nursing care practices. This theory is conceptualized in the 'Sunrise Model'. The aim of this model is a holistic view of the major components of a health care delivery system and how they influence the care and health status of individuals, families, groups and socio-cultural institutions, including decisions about nursing care and actions to achieve culturally-congruent care. For nurses to deliver culturally congruent care in the organ donation and transplant field, it was deemed imperative to examine the worldview and environmental context of patients, especially the cultural and social dimensions that might influence attitudes towards organ donation and transplants, based on the "Sunrise Model". The cultural and socio-structural dimensions analyzed in this model include the technological factors, religious and philosophical factors, kinship and social factors, cultural values and lifeways, political and legal factors, economic factors and educational factors. These factors will be discussed in this article and form the framework of this study.

\section{Technological factors}

Technological factors include organizing activities towards organ retrieval. Identification of potential donors and requests for organs is an expected function of personnel in the intensive care unit, the operating room and the emergency room. Roark (2000:45), however, maintains that $17 \%$ of potential donor families in America are not approached and informed about donation options and another $12 \%$ are missed because health professionals don't recognize and declare brain stem death early enough to preserve the organs. Other reasons for this omission are attributed to ignorance, inexperience and emotional involvement of the health professionals (Maher \& Strong, 1989:135; Coupe, 1990:34; Kawamoto, 1992:1541). This shortcoming could also be related to poor timing of a request in a period of bereavement and faulty selection in relation to physical and psychosocial readiness. Perceived post transplantation problems e.g. lifetime immunosuppressive therapy and psychological reactions of donor families after organ donation could also be factors to consider (Coupe, 1990:35: Odell and Brink, 1992:395; Pike, 1992:12).

\section{Religious and philosophical factors}

Many religions teach that the human body is different from other material possessions in that it is a gift from a supernatural power, such as God, therefore there is a moral obligation to respect the human body. Christians, however, also believe in altruism and therefore regard organ donation as an act of generosity and love for another (Martinelli, 1993:247; Rosen, 1991: 197).

\section{Ethical factors}

Language barriers, illiteracy and the social position of the transplant co-ordinator may jeopardize the right of the bereaved family to informed consent. The transplant coordinator might be tempted to adopt a paternalistic approach (Kapsa. in Boyle \& Andrews, 1989:3). Pike et al (1991:26) point out that the appointment of black transplant coordinators could help with communication. The presumed consent approach is strongly criticized for violating self determination, and is thus deemed suitable for only a well informed public (Strong and Strong, 1985:240; McNatt, 1992:34). Kapsa (in Boyle \& Andrews (1989:318) and McNatt (1992:34), have also observed coercion among family members, thus they suggest donation only among emotionally related family members or close friends.

\section{Kinship and social factors}

A person's age, sex, relationship and community status may influence a decision to participate in organ donation and transplantation. An Arabic male, for example, may not donate to an adolescent female in his clan, even his own daughter (Kapsa, in Boyle \& Andrews, 1989:32). The subordinate position of wives and daughters in a Zulu clan is, probably, responsible for more wives donating to husbands than vice versa, in interspouse organ donation (Bryant, 1967:438; Ngubane, 1977: x; Schleubusch, Bruwer and Bosman, 1991: 7-9).

\section{Cultural factors, beliefs and lifeways}

Zulu- speaking people believe in the Creator (Umvelingqangi, one who appeared before all else) or, if converted to Christianity, God, without question. Therefore they may believe that they have no authority to donate their bodies or organs (Hennig, 1992:32). The strong bond and interdependence between the living and the dead (the ancestors) among Zulu speaking people adds to the fear, as it is believed that if this bond is broken the ancestors will show anger by visitation in the form of ill-health, misfortune or even death. Ritual murders for human tissue or organs for use in witchcraft may accentuate this problem (Conco, 1972:299). 


\section{Economic factors}

In many countries, especially those affiliated to the WHO, the sale of organs is prohibited by law, e.g. The Human Tissue Act (Act no. 65 of 1983) in South Africa. Other countries, e.g. India, The Phillipines, Long Island, etc, have been compelled by shortage of organs to offer incentives like payment of hospital and funeral fees to families of brain stem dead patients (Strong \& Strong, 1985:239; Pike 1992:14; Martinelli, 1993:245; McNatt, 1992:341). Commercializing human organs is criticized because it puts those who can afford transplants at an advantage, and may lead to financial exploitation of the vulnerable (Harries \& DeLone, 1992: 49; Evans, 1993: 34; Health Services International: 1992).

\section{Educational factors}

Some ignorance has been observed among members of the public about the success rate of transplantation, understanding of brain stem death, and fear of donor cards. Barriers to knowledge are mainly language differences and misconceptions about some health care issues (Strong \& Strong, 1985:241; Coupe, 1990:36; Harries and De Lone, 1992:49 and McNatt, 1992:343).

Leininger (1988:158) summarizes the need to consider all the above factors in her promotion of culture-congruent nursing care in agreement with Chrisman's culture sensitive care (cited in Baird, McCorcle \& Grant, 1991: 36-37). These authors argue that people of a particular culture must be enabled to retain and/or preserve core values and practices that have no harmful effect on their health. Professional care providers must negotiate for beneficial health outcomes by adapting their approach to families and communities. Some practices, however, may have to be remodeled or changed.

\section{Purpose and objectives of the study}

The purpose of the study was to determine the extent to which the Zulu structural norms and social structure influence an individual's decision to donate an organ or to undergo a transplant. Representatives of the professional nursing sector, Zulu speaking religious leaders, traditional healers and members of the public were interviewed, with the following objectives:

- To identify aspects of cultural values, beliefs and life practices and of the social structures that influence an individual's decision to donate an organ or undergo a transplant, and

- $\quad$ To make recommendations with regard to the promotion of organ donation and transplantation, based on culture-congruent and culture-sensitive principles.

\section{Research methodology}

This study followed a descriptive, contextual ethno-nursing design using the following processes as described by Leininger (1985: 38):

\section{Identify a domain of inquiry, or area of phenomenon:}

The influence of Zulu culture and social structure on decision making with regard to organ donation and transplantation.

\section{Explore available literature on the phenomenon:}

This study was based on the theory of Leininger (1985:210) as well as the model of Chrisman (in Patrick, Woods, Craven, Rokosky \& Bruno, 1991:36), in which the major objective was to deliver culture-congruent and culture-sensitive care, by taking the cultural dimensions of an individual or community into account.

\section{Prepare research instruments, plans and approvals:}

Two semi structured open-ended interviews were used, namely:

- An interview schedule consisting of three questions that were asked during an interview with the transplant co-ordinator. These questions focused on the experience of the transplant co-ordinator with regard to cultural norms i.e. values, beliefs and practices of the Zulu-speaking people, as these aspects affect attitudes towards organ donation and transplantation.

- An interview schedule consisting of sixteen questions that were asked during interviews with the traditional healers, religious leaders and the general public. These questions focused on the knowledge of transplantation and attitudes towards it, willingness to donate and/or receive organs, beliefs and practices about death, burial and life hereafter and their influence on organ donation and transplantation. Because of the educational differences and the rural nature of the sample, the researcher used a newspaper article about a mother donating one of her kidneys to her son. This article assisted with the orientation of the respondents to the phenomenon under study (City Press, 1994). Permission was obtained from each respondent as well as the administrator of the identified hospital where the transplant co-ordinator was employed and the newspaper to participate in the research study.

\section{Identify and choose the people to be studied:}

The contexts and the sample studied were purposively selected as follows:

\section{Urban and rural context}

Both urban and rural settings were examined because of the differences in perception towards western and traditional medicine, with the latter seemingly being dominant in the rural context. The urban context was within the city 
of Durban, whereas the rural context was eMondlo, in the district of Nquthu. These areas were selected because of their accessibility to the researcher.

\section{Professional sector}

The professional sector was represented by the only transplant co-ordinator in KwaZulu-Natal at the time of the study. Although she did not belong to the majority cultural group, it was felt that her input would be of value as she had worked with Zulu speakers in organ retrieving situations.

\section{Folk sector}

The folk sector was represented by the traditional healers from three categories, the diviner (isangoma); the traditional doctor (inyanga) and the faith healer (umthandazi). These traditional healers were included because their cultural views have an impact on the attitudes of African blacks, $80 \%$ of whom consult traditional healers before seeking western medical help (Conco, 1972:299; Tyler, 1985:36; Hennig, 1992:321). The snowballing technique of sampling was used in which each traditional healer interviewed, was asked to reveal the name and location of another traditional healer who could be interviewed (Polit \& Hungler, 1987:210).

\section{Religious leaders}

African communities respect religious leaders (Mbiti, 1981:11). Values and beliefs are also derived from religion (Martinelli, 1993:247). Representatives from the various denominations were interviewed, including Catholic, Methodist, Lutheran, Anglican, Zionist, Jehova's Witnesses, Dutch Reformed churches and the Church of Nazareth (Shembe). The religious leaders were selected by purposive sampling technique.

\section{Popular sector}

The general public represented the popular sector. Respondents of this sector were selected by purposive sampling technique, with preference given to persons over the age of 50 years because of their role in transmitting cultural values, beliefs and lifeways in the extended families.

\section{Reliability and validity}

Reliability and validity of this study adhere to the qualitative strategies set by Woods \& Catanzaro (1988:136-137), with factors influencing and threatening reliability and validity isolated and control mechanisms implemented. For example, the following were considered: clear identification of the role of the researcher, non-selective recruitment of participants provided they met predetermined research criteria, verbatim transcription of tape-recorded fieldnotes and translation into English, theoretical coding of transcribed data, and comparison of findings with existing literature in the field.

\section{Pilot study}

Eleven (11) people with similar characteristics to the tar- geted respondents were interviewed. The question schedule evoked appropriate answers, and only one change in the order of questions, was made. Because there was only one transplant co-ordinator in the region at the time of the study, she was not included in the pilot study.

\section{Results and discussion}

Forty- eight (48) participants were included in the final sample (see Table 1). A discussion of the information gathered from the interviews follows, grouped according to the questions used in the schedules.

Table1: Participating sample

\begin{tabular}{|l|l|l|l|}
\hline \multirow{2}{*}{ CATFGORIFS } & \multicolumn{2}{|c|}{ SETTING } & TOTAL \\
\hline & URBAN & RURAL & \\
\hline Religious leaders & 8 & 7 & $\mathbf{1 5}$ \\
\hline Traditional Healers & 9 & 9 & $\mathbf{1 8}$ \\
\hline General Public & 7 & 7 & $\mathbf{1 4}$ \\
\hline Transplant co-ordinator & 1 & - & $\mathbf{0 1}$ \\
\hline TOTAL & $\mathbf{2 5}$ & $\mathbf{2 3}$ & $\mathbf{4 8}$ \\
\hline
\end{tabular}

\section{Knowledge and attitude towards organ transplantation}

All the Zulu speaking respondents ( $n=47$ which excludes the transplant coordinator) revealed lack of knowledge about organ transplantation even though they had heard about it in the mass media. Except for the traditional healers, they all expressed the need for more information on the subject. Despite the lack of knowledge, twenty (20) urban and fourteen (14) rural respondents showed some positive attitude towards organ donation and transplantation which may mean that with more knowledge they might be more positive. This possibility was also evident in the studies done in 1992 by the Organ Donor Foundation of Southern Africa. The rural respondents appear to be less positive than the urban. This may be related to the lack of exposure of rural respondents, to the patients that have had transplantation nor to the media in which successful transplantation is published.

\section{Willingness to donate an organ at death:}

Although thirty-four (34) respondents indicated positive attitude towards organ donation, only nineteen (19) of them were willing to donate at death with the rural respondents (11) being less willing than urban ones. The majority preferred live related organ donation, a fact that also came out clearly from the interview with the transplant co-ordinator. Only seventeen (17) respondents would donate on behalf 
Table 2: Willingness to donate an organ at death

after donation or trans-

\begin{tabular}{|l|l|l|l|l|c|}
\hline \multirow{2}{*}{ CATF;ORIFS } & SEITING & INFAVOUR & AGAINST & UNCERTAIN & TOTAL \\
\hline \multirow{2}{*}{ Religious Leaders } & Urban & 4 & 2 & 2 & 8 \\
\cline { 2 - 6 } & Rural & 2 & 1 & 4 & 7 \\
\hline \multirow{2}{*}{ Traditional Healers } & Urban & 3 & - & 6 & 9 \\
\cline { 2 - 6 } & Rural & 1 & 6 & 2 & 9 \\
\hline General Public & Urban & 4 & 1 & 2 & 7 \\
\cline { 2 - 6 } & Rural & 5 & 2 & 0 & 7 \\
\hline TOTAL & & 19 & 12 & 16 & $* 47$ \\
\hline
\end{tabular}

plantation of organs. For example, they would slaughter a goat or burn incense asking for blessings (Ukucela izinhlanhla) from the ancestors before the donation of organs or transplantation or, appease the ancestors (ukushweleza) afterwards in the same way, should the ancestors have been annoyed by the act.

The respondents also needed to be more informed about organ do-

* Excludes the transplant coordinator.

of a deceased relative, because the majority believed that the cadaver donor must have indicated the wish to donate an organ while still alive, rather than the relatives donating on the donor's behalf. This is probably related to their respect for the dead and their wish to live in harmony with their ancestors, as cited by Hennig (1992:34).

\section{Donation to relatives and non- relatives:}

Thirty - two (32) respondents would rather donate to relatives than to non-relatives "It is out of love for the relative which overrides that of a non-relative". Traditional healers and rural respondents had mixed feelings. The traditional healers had some strong reservations even with relatives.

\section{Receiving an organ from a relative or non-relative}

Thirty-two (32) respondents would accept an organ irrespective of the source, yet only nineteen (19) of them would donate to a non-relative. This discrepancy could be attributed to the ambivalence between the two conflicting worldviews, namely, the African and Western ontologies, as identified by Manganyi (1974:924), with the former having a histori-cultural advantage. The traditional healers, especially Sangomas would not accept organs even from relatives as they claim to be under the spell of ancestors who would never accept such. They do, however, acknowledge the selfishness about receiving without donating e.g. "who should give if I must receive only". Ketchum (2003:1) also observed such discrepancy among African Americans in that they account for $13 \%$ of organ donation and $18 \%$ of organ recipients.

\section{Circumstances for donation of organs:}

The respondents, in their wish to maintain harmony with their ancestors, preferred to perform some rituals before or nation and transplantation, including discussion of its success and associated problems e.g. HIV/AIDS. Quotation of verses encouraged the separatist priests who wanted to be convinced by a text from the bible on the subject. The respondents needed to be convinced that their health care would not be compromised in life threatening situations to get their organs if they indicated their wish to donate before death. This might pose a problem, because the same people believe that the deceased must indicate consent before death. Such fears are also evident in previous studies, for example, Simmons (1995:14), with African Americans who feared possession of an organ donor card believing that it might lead to reduction in medical care given in life threatening situations. Concern that the health of the donor should not be affected by organ harvesting related to the myth that surgery has such adverse effects as sensitivity to cold and weakness. The potential recipient must also be an asset to the community, not a menace nor an alcoholic.

\section{Communication of death, burial wishes and organ donation and transplantation:}

Only two (2) respondents had discussed death issues, probably from fear of imminent death, because they believed that such discussion might be a premonition that one was going to die. Worse still, they found organ donation very remote because it was discussed in the media, not by people they knew and trusted for example, community leaders like religious leaders, as proposed by McNatt (1992: 343). Because Zulu communities mainly utilize and trust traditional healers (Tyler, 1985:36), traditional healers could be utilized, with religious leaders, to help make organ donation and transplantation more acceptable.

\section{Values influencing organ donation and transplantation: \\ Altruism:}

Zulu speaking people showed little altruism when they in- 
dicated more willingness to receive than to donate organs. They did show some conscience about this issue in comments, however, which probably came from their mixed feelings: "It is not fair to accept organs when you cannot donate to the outsider".

\section{Voluntarism:}

Zulu speaking people have a strong sentiment for voluntarism from both religious and cultural perspectives. The religious perspective suggests that donation of organs is a religious sacrifice to God, which has to be offered by the person concerned and not by the family on his behalf. From the cultural perspective, the donor must have indicated his/her wish to donate before death, otherwise the relative will be haunted by the ancestors, disturbing the harmony which they so wish to maintain: "I would come back from the dead to demand my organs"; "If my wife allow's it (organ donation), she will never ever sleep because I will haunt her".

\section{Beliefs about death, burial and life hereafter \\ Predestination:}

Ten (10) respondents believed in predestination. Extension of life with support systems and transplantation is contrary to this belief.

\section{Witchcraft:}

Stealing of body parts (ukucwiva) or shadows of persons (ukuthwebula), associated with the frequently published "muthi murders", cast a negative reflection on organ donation. Eight (8) of the respondents, predominantly the traditional healers, did not see the difference between "muthi murders" and organ donation and transplantation.

\section{Ancestor worship:}

Fourteen (14) respondents believed that the deceased join the family of ancestors, therefore, before donating organs or accepting a transplant, the ancestors must indicate approval otherwise the family will be haunted or lose ancestral protection.

\section{Life hereafter}

While forty three (43) respondents admitted that the body decays and only the soul/spirit lives, fourteen (14) of them believed that the body would be affected by organ donation and nine (9) were uncertain about the effect of organ donation on life hereafter. This is probably related to their belief in wholeness or completeness before joining the ancestors or even when going to heaven. This conviction tallies with the African American belief in wholeness for burial (Simmons, 1995: 314).

\section{The importance of certain organs:}

The heart had a certain place for three (3) respondents, "Some parts may be donated but the heart attaches a person to his family". "It is important to know the background of the donor, for example. kind-hearted person for a heart transplant". This may affect hear transplantation adversely for fear of change of character from a "kind-hearted" to an "evil-hearted one". These concerns contrast with the study done by the Organ Donor Foundation (1992), in which the majority of respondents were willing to donate their hearts. This may be related to the geographical area from which the sample was extracted, i.e. closer to the heart transplant centre where its success may have been witnessed. This factor accentuates the importance of the geographical area, transplant activity and community education.

\section{Cultural and social structural Dimensions Technological factors:}

Negative previous experience with general anesthesia seemed to be of concern. Though this concern may affect living related organ donation adversely, it is still preferred by this community to cadaver donation. Respondents felt that surgery was performed even without consent and this meant that organs could also be harvested without consent. Waking up in the mortuary was a concern to almost all the respondents, emphasizing the problem of understanding the diagnosis of brain stem death. This concern was also mentioned by the transplant co-ordinator.

The transplant co-ordinator raised concern that migrant labour increased the distance among family members, making it difficult to reach the relatives to grant consent for organ donation, in face of imminent haemodynamic instability of the cadaver. Furthermore, organ donation was affected in KwaZulu-Natal by the shortage of staff in overcrowded intensive care units, especially in identifying and approaching potential donors and families. The shortage of ventilators to maintain donors worsened the problem, yet. even under normal circumstances, Coupe (1990:3), maintains that ICU nurses are subjected to an extra workload by maintaining compromised recipients while waiting for the donor.

\section{Religious and philosophical factors:}

Hoping for God healing power confused one respondent as to when to stop hoping for recovery and accept brain stem death. As a religious sacrifice, organs needed to be offered for donation by the person concerned yet the same people feared discussing death issues. Coercion seemed to be a problem in the interspouse organ donation, especially husbands coercing wives. This was clearly revealed by the transplant co-ordinator who indicated that women would even be threatened, "if you do not give me your kidney, I will take the children away from you". Coercion is probably related to the imposed position of women in this culture as subordinate to men. The same problem is cited in Kapsa (in Andrews \& Boyle, 1989:318), among family members who expect the member with matching blood results to consent automatically to organ donation to the relative.

\section{Kinship and social factors:}

Decision making about the deceased and burial is better 
done jointly, even including the in-laws, especially brotherin-law. This was also identified by transplant co-ordinator and confirmed by authors like Bryant ( 1967:438) and Reader (1966:33), though Manganyi ( 1974:923) indicates a shift from this kinship pattern to the emergence of a nuclear family. Male members, however, still dominated decision-making. The transplant co-ordinator revealed that when wives needed an organ, they would go to their own relatives, not husbands or in laws. The decision to donate was also affected by the feeling for that person, for example, a parent would be more willing to donate to a co-operative child in the family.

\section{Education and language:}

Many misconceptions were identified as due to knowledge and communication problems. The researcher identified confusion between renal function and sexuality. Some feared reproducing a different offspring, change of sex and confusion of sexually transmitted diseases with renal disease. "There is no need for transplantation, I can cure ilumbo", meaning a disease whose cause or origin is unknown. "Is that recipient still a male?" (Referring to the newspaper article where a mother had donated a kidney to her son). "I may get a different offspring from mixing organs".

Most respondents knew about kidney and heart transplantation but some expressed a need for more information on the subject. They also preferred direct contact when discussing the issue of organ donation and transplantation. The transplant co-ordinator, as an English- speaking South African also expressed the problem of communication with Zulu-speaking people. This is consistent with the recommendations by Buthelezi (1992), that the translator be conversant not just with the language but also with the patient's culture and worldview.

\section{Political Factors:}

Traditional healers tended to compare traditional medicine in an attempt to be recognized in the health care system. "We can cure some diseases and not others just like western doctors". One (1) traditional healer quoted an incidence of discrimination against traditional healers when one traditional healer was arrested because he was found with a human hand, yet western doctors are allowed to use human organs for treatment. The power of decision making for a Zulu woman is still dominated by male members of the family as women are considered strangers in the family by marriage and as full members only after menopause (Ngubane, 1977:54). This trend is changing in the urban setting as ten (10) respondents in this study left the final decision to their wives.

\section{Conclusions}

This study revealed that the Zulu-speaking respondents lacked knowledge on organ donation and transplantation. However, they had some positive attitude towards organ donation and transplantation, which could be reinforced with adequate education. These respondents also preferred live-related than cadaver organ donation. Decision making like consent for organ donation and transplantation still lays with the extended families especially the male counterparts. Death issues are not normally discussed because such talk is associated with premonition that a person would die. The Zulu speaking people prefer to live in harmony with their ancestors therefore they would rather perform rituals like slaughtering goats to inform the ancestors before organ donation and transplantation or appease the ancestors if these procedures had to be done before rituals were performed. The respondents feared that their health care in life threatening situations would be compromised by the need for organs if willingness to donate was indicated early. Rural respondents and the traditional healers seem to be more rigid with these convictions than their urban counterparts.

\section{Recommendations}

According to Bodner and Leininger (1986:25), the nurse in caring for the client, needs to understand and use ethnohistory, cultural values and the client's health practices for specific care actions and decisions to attain culturally-congruent nursing care. Chrisman (in Baird, McCrocle \& Grant, 1991:46), also advocates a culture sensitive care, which must take into account the cultural background of patients. The researcher, therefore, having assessed the cultural influences on Zulu speaking people, in so far as organ donation and transplantation are concerned, recommends the following:

\section{Culture- care preservation and maintenance:}

Values, beliefs and practices, as well as social structures can be accommodated as follows:

\section{Ancestor worship:}

Zulu speaking people could be allowed to perform ritual sacrifices, to inform ancestors about organ donation and transplantation or appease ancestors if they wish to do so.

\section{Extended families:}

The family as a whole, including extended family members should be approached to secure consent, and adequate time must be allowed for them to discuss the issue. The transplant co-ordinator stressed this. Adult female members of the family must be included specifically during discussions because of their caring role and respect given to them in Zulu culture.

\section{Preference for live donation:}

Zulu-speaking people should not be rushed into cadaver donation but should be introduced to the topic slowly to allow them to get used to the idea, as there is a relationship between knowledge, experience and attitude.

\section{Traditional ways of identifying death:}

A traditional healer could be incorporated to make a diagnosis of death as a trusted person in the Zulu community. 
This would also prevent doubt about the concept of brain stem death.

\section{Culture care accommodation and negotiation: Knowledge:}

Knowledge of Anatomy and Physiology of transplantable organs should be improved through culture-sensitive educational campaigns, to remove misconceptions and myths about those organs, especially the heart and the kidney. Special attention must be paid to traditional healers, who reflected the most misconceptions, yet they are trusted members of the Zulu community and could in turn be utilized, for educational campaigns on the topic.

\section{Fear of discussing death:}

Fear of discussing death, can only be accommodated temporarily while it is being dispelled gradually because, while Zulu speaking people have this fear, they prefer to donate organs themselves while still alive and not have the donation made by relatives on their behalf. Organ donation and transplantation should be discussed, including discussion of death. This includes writing of advanced directives so that they are able to indicate their wish to donate organs. A daughter-in- law could then carry out the wishes of her husband without showing contempt for the in-laws or extended family.

\section{Religious beliefs}

Bible-teaching about extension of life with life support systems and healing could be negotiated by quoting such verses as may favour extension of life. Religious leaders could be utilized to work on this project, e.g. the raising of Lazarus.

\section{Culture-care, repatterning and restructuring:}

Restructuring of institutions or the health care systems could be undertaken to accommodate or negotiate the above mentioned values, beliefs and the social structures of Zulu speaking people as follows:

\section{Incorporation of traditional healers into health care system:}

Traditional healers can attend to the ancestor worship and ritual sacrifices that may have to be performed, as they share the same culture, beliefs and values as their patients. Karim, Ziqubu-Page \& Arendse ( 1994: 14), maintain that traditional healers are skilled in interpersonal relations, including counseling. Before the traditional healers are involved, they should be educated with regard to organ donation and transplantation, and other issues such as Anatomy and Physiology. This would also help with the referral of clients before they developed end-stage organ failure. Incorporation should not be a problem because the present government is already moving towards this change, as stated in the National Health Plan (ANC, 1994). Karim et al (1994:14), also maintain that traditional healers are prepared to consider changing to safe practices, or possibly eliminate those traditional remedies and practices which have proved harmful to patients. The traditional healer must be included throughout the caring process so that they may understand the value of continuing with immunosuppressant therapy post discharge.

\section{Public awareness campaigns:}

Public awareness campaigns need to be embarked on to encourage organ donation and acceptance of transplantation so that consent is given voluntarily by the people themselves while still alive. Anatomy and physiology should be explained to avoid confusion about organs and their functions; transplantable organs and the success rate of transplantation should be discussed, and criteria for organ donation and transplantation should be explained.

\section{How to indicate wish to donate organs \\ The following topics should be clarified:}

Legal aspects to ensure credibility of brain stem death tests; organ donation and transplantation as against "muthi-murders"; explanation of informed consent including the superintendent's consent and the importance of communicating the wish to donate organs.

\section{- Implementers of educational campaigns:}

Community Health Nurses should be included for their close contact with the community and because most of them are of the same culture as their community. Traditional healers should be utilized especially to clear the cultural aspect of organ donation and transplantation. Religious leaders could assist with explanation of religious aspects. Staff of the same culture in the transplant unit needs to use understandable terminology and phraseology. Transplantees and live donors can discuss the effect of transplantation and organ donation respectively. Community organizations such as burial clubs/societies could be seen as target groups, as they are already engaged in activities of preparing for death.

\section{- How to implement educational programmes}

Educational campaigns should be done throughout the year while the Zulu-speaking people are being familiarized with the idea of organ donation and transplantation. Community Health Nurses could be asked to include the issue of organ donation and transplantation in their existing health education programmes. Use of media necessitates assessment of the widely used media and in case of television or radio the highest listener time should be used when the families are together in order to trigger discussions.

\section{Teaching methods to be used:}

Seminars, panel discussions and conferences, including phone-in programmes, could be organized and presenta- 
tions in churches with predominantly black congregations. Open days could also be organized and people invited to see the functioning of haemodialysis and transplant units. Respondents could then compare the expenses involved in these procedures. People who know the subject and are experienced in the field; able to answer questions appropriately and anticipate concerns about organ donation and transplantation, must control discussions held in the media.

\section{- Culture-sensitivity}

Nursing personnel must know the main aspects of the cultures within which they work, such as language, values, beliefs and life practices. They must respect these aspects and consider them in the care plans, health education programmes and discharge plans. This in turn will encourage the communities to respect and trust the health institutions, thereby opening opportunities for negotiated settlements of cultural differences as already indicated.

Should there be any mishaps in the hospital especially related to surgery, they must be thoroughly explained to patients and families so that they do not associate the issues incorrectly. The corpse must be kept long enough in the ward to ensure that the patient is dead to avoid confusion about brain stem death. The relatives could as much as possible be called into the units if death is imminent to witness death.

The public must be kept informed of diagnostic technological advancement to promote credibility of brain stem death. That respondents related to 'muthi killing' and illegal possession of parts of the deceased person's body reinforces that health workers must clearly distance themselves from practices that are aligned to witchcraft, when explaining about scientific therapeutic organ donation and transplantation.

Other health professionals for example, hospital chaplains, social workers, physicians and transplant co-ordinators must be utilized to approach family members of prospective donors because of the ethical constraints nurses have to deal with during the grieving period as also suggested in the study by Danneffel, Kappes, Waltimire and Yearwood (1992:127). Zulu speaking nurses should approach potential donors in the Zulu community. A similar action with St Louis African Americans improved the consent rates from $34 \%$ to $48 \%$ (Kappel, Whitlock, Parks-Thomas, Hong and Freedman, 1993:2490).

\section{Summary}

The authors have determined the extent to which Zulu cultural and social structural dimensions influence decision to donate organs or accept transplantation, within a particular context. Findings compare with studies done in other countries among black communities. Areas of common concern are knowledge deficits, need for completeness at burial, fear of discussing death, fear of compromised care if willingness to donate is indicated early, religious fears, superstitions and language differences (Plawecki, Freiberg \&
Plawecki, 1989: 323).

However, this study cannot be generalized beyond its context, due to the small size of the sample.

\section{Bibliography}

AFRICAN NATIONAL, CONGRESS 1994: A National Health Plan for South Africa, Johannesburg. ANC.

BODNER, A \& LEININGER, M 1986: Transcultural Nursing Care. Journal of Trnscultural Nursing 4(1). Summer.

BOYLE, JS \& ANDREWS, MM 1989: Transcultural Concepts in Nursing Care, $I^{\text {st }}$ edition. Illinois: Foreman and Company, Brown College Division.

BRYANT, AT 1967: Zulu people as they were before the White man came. Pietermaritzburg, Shuter and Shooter.

BUTHELEZI, NC 1992: Communication skills of Black nurses with reference to their processing of information between doctors and patients. A Thesis, University of $\mathrm{Na}$ tal.

CALLENDER, CO 1987: Organ Donation in Blacks. A community approach. In Pike, RE; Kahn, D; \& Jacobson, JE 1991: Organ Donation in Developing countries. Nursing RSA Verpleeg. 7(10). 12-14.

CHRISMAN, NJ 1991: Cultural Systems. In Baird, S; McCorkle, R \& Grant, M (EDS), Cancer Nursing: A comprehensive textbook. Philadelphia: W B Suanders Co, 45-54.

CHRISMAN, N.J 1991: Culture-sensitive Nursing care. In Patrick, M; Woods, S; Craven, J; Rokosky, J \& Bruno, P (Eds), Medical- Surgical Nursing: Pathophysiologic Concepts, $2^{\text {nd }}$ edition, Philadelphia: Lippincott, 34-36.

CITY PRESS 1994: Loving mom saves son's life. Johannesburg.

CONCO, W2 1972: The African Bantu traditional practice of medicine. Soc. Sc. And Med. vd 6:283-301.

COUPE, D 199): Donation Dilemmas. Nursing Times. 86(27) $34-36$.

DANNEFFEL, MB, KAPPES, JE, WAL'TIMIRE, II D \& YEARWOOD, I 1992: Knowledge and Attitudes of Health Care Professionals about Organ Donation in a Hispanic Population. Transplantation Proceedings. 23(2) April 1991: 18041806.

EVANS, M 1993: Moral Costs. Nursing Times 89(37) September. 34-35.

HARRIES, JS \& DELONE, PA 1992: Allocation of Cadaver Kidneys. Anna Journal 19(1), February (1992) health services international 1992: Commerce in Human Organs. HIHFI, number 17 47-49. 
HENNIG, W 1992: Traditional Healers: Hocus-Pocus or The Way to Health. Sundav Times Magazine. no. 40. November:32-36.

http://www.geocities.com/humanoffal/section27. 2003. 1-13.

KAPPEL, DF; WHITI OCK, ME; PARKS-THOMAS, TD; HONG, BA ; FREEDMAN, BK 1993: Increasing AfricanAmerican Organ Donation: St Louis Experience. Transplantation Proceedings 5(4). August 1993: 2489-2490.

KAPSA, C 1989: Organ Transplants: Cultural Issues and Moral Problems. In Boyle, JS \& Andrews, MM 1989: Transcultural Concepts in Nursing Care, $1^{\text {st }}$ edition. Illinois: Foreman and Company, Brown College Division.

KARIM,SSA; ZIQUBU-PAGE, TT \& ARENDSE, R. 1994: Bridging the Gap: Potential for a Health Partnership between African Traditional Healers and Biomedical Personnel in South Africa. SAMJ, December p 1-16.

KAWAMOTO, KL 1992: Organ Procurement in the Operating Room. AORN JOURNAL 55(6), June, pl 541-1546.

KETCHUM, PR 2003: National Campaign to Increase African American Organ Donation. http://www.newswise.com/ articles/view/36579/.

IEININGER, MM 1978: Transcultural Nursing: Concepts, Theories and Practices. London: Wiley.

I.EININGER, MM 1985: Qualitative Research Methods in Nursing. New York: Grune and Straton, inc.

LEININGER, MM 1988: Leininger's Theory of Nursing, Culture Care Diversity and Universality. Nursing Science Quarterly 1(4). November, pl.52-160.

MAHER, ME \& STRONG, S 1989: Organ Donation: A Nursing Perspective. Journal of neuroscience Nursing $21(6)$ December 1989: 357-360.

MANGANYI, NC 1974: Health and Disease- Some Topical Problems of Socio-Cultural Transition. South African Medical Journal 48. p922-924.

MARTINELII, AM 1993: Organ Donation: Barriers, Religious Aspects. AORN 58(2) August, p236-251.

MBITI, JS 1981: Introduction to African Religion. London: Heinemann.

MCNATT, G 1992: Testimony: Controversy in Organ Donation. Anna Journal 19(4) August, p341-343.

NGUBANE, $\mathrm{H}$ 1977: Body and Mind in Zulu Medicine: An Ethnography of Health and Disease in Nyuswa-zulu Thought and Practice, New York: San Francisco Academic Press.

ODEIL, JA \& BRINK, JG 1992: Heart Transplantation in
South Africa- A critical appraisal. SAMJ 82 December 1992:394-396.

ORGAN DONOR FOUNDATION OF SOUTHERN AFRICA 1992: Annual Report: Cape Town.

PIKE, RE 1992: Organ Donation in developing countries. Nursing RSA Verpleeg 7(10) 12-14.

PIKE, RE; KAHN, D\& JACOBSON JE 1991: Demographic Factors Influencing Consent for Cadaver Organ Donation. SAMJ 79. March 1991: 264-267.

PI.AWECKI, H M; FREIBERG, G \& PI AWECKI,JA 1995: Increasing organ donation in the black community. ANNA Journal. 16. 321-324.

POI.IT, DF \& HUNGIER, BP 1987: Nursing Research Principles and Methods $3^{\text {rd }}$ edition, Philadelphia: J P Lippincott Company.

RAZEK, T; OLTHOFF, K \& REILIY, PM 20M): Issues in Potential Organ Donor Management. Surgical Clinics of North America 80(3). June. p1021 - 1030.

READER, DH 1966: Zulu tribe in Transition: The Makhanya of Southern Natal. Manchester University.

ROARK, DC 2000: Overhauling the Organ Donation System. Americian Journal Of Nursing. 1(0)(6): $p$ 44- 48.

ROSEN, SI 1991: Understanding and Increasing Black Kidney Donation. ANNA Journal 18(2). p 195-198.

RSA, 1983: Human Tissue Act (Act No. 65 of 1983), as amended.

SCHLEUBUSCH, L; BRUWER, MN \& BOSMAN, EA 1991: Interspouse Donor Decisions in Renal Transplants. Membrane 11(1) April 1991:7-9.

SIMMONS, DE 1995: Significance of increasing organ donation by African-Americans and implications for nursing practice. Anna Journal 22(3) June 1995:313-317.

STRONG, M \& STRONG, C 1985: The shortage of Organs: Transplantations. ANNA Journal. 12(4) August 1985.

TYLER, P 1985: African Tribal Medicine and its role in Modern Nephrology. EDTNA Journal. V November 1985: 3.-40.

WOODS, NF \& CATANZARO, M 1988: Nursing Rescarch: Theory and Practice. St Louis: CV Mosby Co.

YANG, SI; ABRAMS, J; SMOLINSKI, S \& NATHAN, H 1993: Organ Donation Among African-Americans. Transplantation Proceedings. 25(4). p2487-2488. 